\title{
FINANCIAL INCLUSION SEBAGAI UPAYA PEMBERDAYAAN PEREMPUAN MELALUI SISTEM GRAMEEN BANK
}

\author{
Ahmad Zaki Muntafi \\ Universitas Islam Negeri (UIN) Syarif Hidayatullah Jakarta \\ E-mail: moentafy@gmail.com
}

\begin{abstract}
Abstrak: Usaha peningkatan jasa keuangan di tengah masyarakat sangat diperlukan sebagai upaya dalam mewujudkan efisiensi ekonomi dengan hasil yang maksimal. Dalam hal ini pemerintah meluncurkan program national strategy financial inclusion (NFSI) untuk memperluas akses masyarakat dalam usaha jasa keuangan. Untuk memaksimalkan program tersebut sistem grameen bank bisa menjadi solusi yang tepat, khususnya bagi pemberdayaan perempuan miskin yang memiliki produktivitas dan berada di pedesaan. Sistem grameen bank sebagai kredit mikro yang tidak terikat dengan perjanjian, sehingga sistem ini tidak memberatkan bagi perempuan yang memiliki ekonomi tergolong miskin. Selain itu, sistem gremeen bank berlandaskan dan berorientasi pada kepedulian sosial, khususnya dalam pengentasan kemiskinan.
\end{abstract}

Kata kunci : financial inclusion, grameen bank, pemberdayaan perempuan

\section{PENDAHULUAN}

Suatu negara dalam proses perkembangannya membutuhkan strategi dan kebijakan khusus yang disesuaikan dengan sasaran dan target pembangunannya. Setiap negara juga menginginkan kondisi ekonomi yang stabil dan berkelanjutan dalam mensejahterakan rakyatnya. Kondisi ekonomi yang stabil dan baik menjadikan penilaian terhadap perkembangan dan pembangunan suatu negara. Dalam hal ini, kondisi ekonomi dapat dijadikan tolok ukur untuk menentukan tingkat prosentase pembangunan yang telah dicapai. Semua bidang kehidupan pada dasarnya dapat dipengaruhi dari kondisi ekonomi, semakin baik kondisi ekonomi akan menjadikan dampak yang baik dalam bidang lain, serta sebaliknya.

Dalam proses pembangunan suatu negara dibutuhkan partisipasi dari semua elemen masyarakat, dimana secara lebih jauh lagi diharapkan akan terciptanya hubungan kemitraan yang baik diantara masyarakat, sehingga akan terjadi proses timbal balik yang akan saling menguntungkan. Kemitraan yang terjalin dengan baik akan mampu mendorong percepatan pertumbuhan ekonomi masyarakat. Namun, menurut Kutut Suwondo (2005), dalam proses kemitraan dibutuhkan juga fungsi secara efektif dari pemerintah, adanya keteladanan pemimpim, serta partisipasi aktif masyarakat. Dalam hal ini, pemerintah sebagai pemegang kebijakan harus mampu memaksimalkan perannya terhadap masyrakat, serta adanya partisipasi dari masyarakat merupakan proses kemitraan yang baik, dimana masyarakat sebagai pengawas kinerja pemerintahan.

Mengenai kesuksesan pembangunan suatu negara, dapat didasarkan dan dilihat pada kondisi dan tingkat partisipasi perempuannya dalam masyarakat, dimana perempuan memegang peranan penting dalam kehidupan, mulai dari dalam keluarga, masyarakat, hingga negara. Namun, terkadang peranan penting tersebut tidak dianggap maupun belum 


\section{2-13 | HARKAT: Media Komunikasi Islam Tentang Gender dan Anak, 11 (1), 2015}

mendapat perhatian secara lebih sebagai faktor penentu kesuksesan pembangunan. Dalam hal ini, mengakibatkan terjadinya ketidakberdayaan perempuan dalam partisipasinya ditengah masyarakat demi kelangsungan hidupnya, khususnya perempuan di daerah pedesaan yang memiliki akses terbatas. Selain ketidakberdayaan, juga terdapat keterbelakangan mengenai struktural (kebijakan) dan kultural (Usman, 2004).

Sementara ini, masyarakat pedesaan masih tertinggal dalam segi pembangunannya dibandingkan dengan daerah perkotaan. Menurut Todaro, sebagaimana dikutip oleh Jaka Sriyana (2010), terdapat ketidakseimbangan antara kota dan desa, dimana dapat dilihat pada dua sisi. Pertama, dari sisi penawaran (supply), dengan adanya perpindahan penduduk secara terus-menerus, maka terjadi arus urbanisasi secara berlebihan, sehingga meningkatkan jumlah pertambahan penduduk perkotaan. Bertambahnya jumlah penduduk berdampak pada penawaran tenaga kerja di kota semakin meningkat, sedangkan di desa semakin sedikit. Kedua, dari sisi permintaan (demand), penciptaan tenaga kerja di kota lebih sulit dan mahal daripada di desa, dikarenakan adanya kebutuhan yang lebih banyak pada pekerjaan di sektor industri. Dalam hal ini, untuk membuka sektor industri lebih banyak membutuhkan biaya, sedangkan di desa membutuhkan lebih sedikit biaya untuk sektor pertanian tradisional maupun sejenisnya. Oleh sebab itu, hal ini juga dapat menjadi pertimbangan dalam memberdayakan perempuan desa.

Dewasa ini beberapa konsep pembangunan lebih ditekankan pada aspek kesejahteraan terhadap perempuan, sehingga kondisi perempuan yang mengalami ketidakberdayaan peran dalam masyarakat membutuhkan sebuah usaha dalam memberdayakannya, dengan harapan akan tercapai kemandirian dan kesejahteraan yang baik bagi perempuan. Terkait dengan itu, pemerintah membuat kebijakan national strategy financial inclusion (NFSI), yang bertujuan untuk mempermudah akses masyarakat dalam jasa keuangan. Adanya financial inclusion menjadikan salah satu solusi dalam memberdayakan perampuan, dimana strategi tersebut dapat dilakukan dengan menerapkan sistem grameen bank dalam usaha memberdayakan perempuan. Sistem ini didasarkan pada usaha pengentasan kemiskinan, yang dikhususkan pada pemberdayaan perempuan yang memiliki ekonomi miskin, tetapi memiliki produktivitas. Hal itu dilakukan dengan melalui pemberian kredit mikro. Selain itu, sistem ini juga sebagai upaya dalam meningkatkan taraf hidup masyarakat di pedesaan, sehingga masyarakat pedesaan mampu bersaing secara maksimal dalam dunia perekonomian. Berdasarkan latar belakang di atas, maka penulis dapat memberikan beberapa rumusan masalah, antara lain :

1. Bagaimana pemberdayaan perempuan?

2. Bagaimana kredit mikro sebagai solusi pemberdayaan perempuan?

3. Bagaimana sistem grameen bank?

\section{KERANGKA TEORI}

\section{Financial Inclusion}

Financial inclusion adalah suatu kegiatan menyeluruh yang bertujuan untuk menghilangkan segala bentuk hambatan, baik dalam bentuk harga ataupun non-harga terhadap akses masyarakat dalam menggunakan atau memanfaatkan layanan jasa keuangan, serta sebagai strategi nasional untuk mendorong pertumbuhan ekonomi melalui pemerataan pendapatan, pengentasan kemiskinan serta stabilitas sistem keuangan (Departemen Pengembangan Akses, 2014).

Financial inclusion telah menjadi agenda penting ditingkat internasional maupun nasional. Ditingkat internasional, financial inclusion telah 
dibahas dalam forum G20, OECD, AFI, APEC dan ASEAN, dimana Indonesia berpartisipasi aktif didalamnya. Sedangkan ditingkat nasional, komitmen pemerintah telah disampaikan Presiden RI dalam Chairman Statement pada ASEAN Summit 2011 dan komitmen untuk memiliki national strategy financial inclusion (NFSI). Dalam strategi financial inclusion dijabarkan dalam enam pilar yaitu: edukasi keuangan, fasilitas keuangan publik, pemetaan informasi keuangan, kebijakan atau peraturan pendukung, fasilitas intermediasi dan distribusi, serta perlindungan konsumen (Departemen Pengembangan Akses, 2014).

Usaha financial inclusion juga telah sesuai Instruksi Presiden Nomer 3 tahun 2010 tentang program pembangunan yang pro rakyat. Selain itu, financial inclusion juga memiliki beberapa tujuan, antara lain:

1. Menjadikan strategi keuangan inklusif sebagai bagian dari strategi besar pembangunan ekonomi, penanggulangan kemiskinan, pemerataan pendapatan dan stabilitas sistem keuangan.

2. Menyediakan jasa dan produk keuangan yang sesuai dengan kebutuhan masyarakat.

3. Meningkatkan pengetahuan masyarakat mengenai layanan keuangan.

4. Meningkatkan akses masyarakat ke layanan keuangan.

5. Memperkuat sinergi antara bank, lembaga keuangan mikro, dan lembaga keuangan non-bank.

6. Mengoptimalkan peran teknologi informasi dan komunikasi (TIK) untuk memperluas cakupan layanan keuangan (Departemen Pengembangan Akses, 2014).

\section{Pemberdayaan}

Pemberdayaan menurut bahasa berasal dari kata "daya" yang berarti tenaga atau kekuatan, proses, cara, perbuatan memberdayakan (Pusat Bahasa, 2002). Pemberdayaan juga sebagai terjemahan dari empowerment, sedangkan memberdayakan adalah terjemahan dari empower. Menurut Merriam Webster dan Oxford English Dictionary, kata empower mengandung dua pengertian, yaitu: 1) to give power atau authority to atau memberi kekuasaan, mengalihkan kekuatan atau mendelegasikan otoritas ke pihak lain; 2) to give ability to atau enable atau usaha untuk memberi kemampuan atau keperdayaan. (Oxford, 2008).

Konsep pemberdayaan lahir sebagai antitesis terhadap model pembangunan dan model industrialisasi yang kurang memihak pada rakyat mayoritas. Konsep ini dibangun dari kerangka sebagai berikut : 1) bahwa proses pemusatan kekuasan terbangun dari pemusatan penguasaan faktor produksi; 2) pemusatan kekuasaan faktor produksi akan melahirkan masyarakat pekerja dan masyarakat yang pengusaha pinggiran; 3) kekuasaan akan membangun bangunan atas atau sistem pengetahuan, sistem politik, sistem hukum, dan ideologi yang manipulatif untuk memperkuat dan legitimasi; dan 4) kooptasi sistem pengetahuan, sistem hukum, sistem politik, dan ideologi, secara sistematik akan menciptakan dua kelompok masyarakat, yaitu masyarakat berdaya dan masyarakat tunadaya (Projono, 1996).

Dalam hal ini, pemberdayaan masyarakat, khususnya bidang ekonomi merupakan usaha penguatan pemilikan faktor-faktor produksi, penguatan penguasaan distribusi dan pemasaran, penguatan masyarakat untuk mendapatkan gaji atau upah yang memadai, dan penguatan masyarakat untuk memperoleh informasi, pengetahuan dan ketrampilan, yang harus dilakukan secara multi aspek, baik dari aspek masyarakatnya sendiri, maupun aspek 
kebijakannya. Karena persoalan atau isu strategis perekonomian masyarakat bersifat lokal spesifik dan problem spesifik, maka konsep dan operasional pemberdayaan ekonomi masyarakat tidak dapat dirumuskan secara generik. Usaha merumuskan konsep, pendekatan, dan bentuk operasional pemberdayaan ekonomi masyarakat secara generik, memang penting, tetapi yang jauh lebih penting, adalah pemahaman bersama secara jernih terhadap karakteristik permasalahan ketidakberdayaan masyarakat di bidang ekonomi. Sebab, dengan pemahaman yang jernih mengenai ini, akan lebih produktif dalam merumuskan konsep, pendekatan, dan bentuk operasional pemberdayaan ekonomi masyarakat yang sesuai dengan karakteristik permasalahan lokal maupun global.

Menurut Jaka Sriyana (2010), usaha pemberdayaan masyarakat dapat dilihat dari tiga sisi. Pertama, menciptakan suasana atau iklim yang memungkinkan potensi masyarakat berkembang (enabling). Hal ini menekankan peningkatan potensi masyarakat, baik secara individu maupun kelompok.

Kedua, memperkuat potensi atau daya masyarakat (empowering). Tidak hanya menciptakan iklim dan suasana dalam pemberdayaan, tetapi juga diperkuat dengan langkah-langkah nyata yang menyangkut penyediaan berbagai masukan (input), serta pembukaan akses berbagai peluang (opportunities). Ketiga, memberdayakan mengandung pula arti melindungi. Masyarakat yang lemah perlu dicegah menjadi bertambah lemah, dikarenakan kekurangberdayaan dalam menghadapi yang kuat. Oleh karena itu, perlindungan dan pemihakan kepada yang lemah sangat mendasar sifatnya dalam konsep pemberdayaan masyarakat.

\section{METODE PENELITIAN}

Dalam penelitian ini, penulis menggunakan metode pustaka (riblary research), yaitu penelitian dalam bentuk kajian teorotis terhadap suatu permasalahan. Studi pustaka juga dapat dikatakan sebagai studi pendahuluan, dalam pengumpulan informasi dapat dilakukan pada tiga objek, dimana objek tersebut dapat dihubungi, dilihat, diteliti atau dikunjungi, serta dapat memberikan informasi yang dibutuhkan. Ketiga objek tersebut berupa tulisan (paper), manusia (person), dan tempat (place) (Suharsimi, 2009).

\section{HASIL DAN PEMBAHASAN}

\section{Pemberdayaan Perempuan \\ Problematika Peran Perempuan}

Dalam kehidupan bermasyarakat perempuan masih dianggap sebelah mata. Meskipun telah banyak upaya dalam melakukan emansipasi bagi perempuan, tetapi masih terdapat cara pandang yang menyudutkan perempuan. Hal itu terkait dengan masalah peran dan citra perempuan yang berkaitan dengan dua hal. Pertama, masalah seks dan gender, masalah penampilan fisik yang membedakan perempuan dari laki-laki secara kodrati, sedangkan masalah gender adalah masalah sosio-budaya, dimana didasarkan atas simbol-simbol didalam masyarakat. Dalam hal ini, perempuan diberi simbol lemah-lembut, keibuan, cantik, serta emosional, sedangkan lakilaki diberi simbol kuat, perkasa, jantan, serta rasional. Dengan demikian, perbedaan simbolis tersebut dapat menimbulkan perspektif bahwa perempuan lebih lemah dari laki-laki.

Kedua, masalah status sosial, dalam stratifikasi sosial masyarakat di Indonesia, pada umumnya dikenal tiga lapisan masyarakat, yaitu : kaum bangsawan (kelompok aristokrat) yang menempati lapisan atas, kaum yang lebih rendah yaitu wong cilik (Jawa), serta rakyat biasa, atau cacah (Sunda). Bahkan, dibeberapa kalangan etnis tertentu ada juga strata diantara keduanya, misalnya dalam masyarakat Sunda dikenal strata santana. Dengan demikian, terdapat perempuan 
yang termasuk dalam kaum bangsawan dengan segala hak istimewa yang dimilikinya, dan terdapat perempuan dalam golongan wong cilik yang harus menerima statusnya sebagai rakyat kecil.

Selain itu, permasalahan mendasar dalam pembangunan pemberdayaan perempuan yang terjadi selama ini adalah rendahnya partisipasi perempuan dalam pembangunan, serta masih adanya berbagai bentuk praktik diskriminasi terhadap perempuan. Permasalahan mendasar lainnya adalah masih terdapat kesenjangan partisipasi politik kaum perempuan yang bersumber dari ketimpangan struktur sosiokultural masyarakat. Dalam konteks sosial, kesenjangan ini mencerminkan masih terbatasnya akses sebagian besar perempuan terhadap layanan kesehatan yang lebih baik, pendidikan yang lebih tinggi, dan keterlibatan dalam kegiatan publik yang lebih luas.

\section{Konsep Pemberdayaan Perempuan}

\begin{tabular}{lr}
\multicolumn{1}{c}{ Pemberdayaan sebagai proses } \\
mengembangkan, \\
menswadayakan, memperkuat posisi tawar
\end{tabular}
menawar masyarakat lapisan bawah terhadap kekuatan-kekuatan penekan disegala bidang dan sektor kehidupan (Sutoro, 2002). Pemberdayaan juga merupakan transformasi hubungan kekuasaan antara laki-laki dan perempuan pada empat level yang berbeda, yaitu: keluarga, masyarakat, pasar, dan negara. Menurut Zakiyah (2010), konsep pemberdayaan perempuan dapat dipahami dalam dua konteks. Pertama, kekuasaan dalam proses pembuatan keputusan dengan titik tekan pada pentingnya peran perempuan. Dalam hal ini, segala bentuk kebijakan dari pemerintah dapat memberikan manfaat bagi perempuan, serta tidak merugikan perempuan. Kedua, pemberdayaan dalam term yang berkaitan dengan fokus pada hubungan antara pemberdayaan perempuan dan akibatnya pada laki-laki dimasyarakat yang beragam. Hal ini berkaitan dengan manfaat yang akan dicapai dalam keluarga, sehingga laki-laki sebagai suami secara perlahan akan berusaha meningkatkan produktivitasnya, serta melalui pemberdayaan perempuan akan mampu meningkatkan taraf ekonomi keluarga.

Selain itu, terdapat dua ciri dari pemberdayaan perempuan. Pertama, sebagai refleksi kepentingan emansipatoris yang mendorong masyarakat berpartisipasi secara kolektif dalam pembangunan. Kedua, sebagai proses keterlibatan individu atau masyarakat dalam proses pencerahan, penyadaran dan pengorganisasian kolektif, sehingga mereka dapat berpartisi (Zakiyah, 2010). Disamping itu, dalam cakupan pemberdayaan perempuan tidak hanya pada level individu, tetapi juga pada level masyarakat atau kelompok dan pranatapranatanya, yakni dengan menanamkan pranata nilai-nilai budaya, seperti : gotong royong, kerja keras, keterbukaan, dan tanggung jawab bersama.

\section{Pentingnya Pemberdayaan Perempuan}

Millenium Development Goals atau MDGs telah ditandatangani oleh pemerintah Indonesia bersama 189 negara lain dalam Pertemuan Puncak Millenium di New York pada September tahun 2000. Salah satu sasaran dan target dalam pembangunannya adalah kesetaraan gender dan pemberdayaan perempuan. Kedua hal tersebut dianggap penting, karena keberlangsungan hidup dalam bermasyarakat sangat tergantung pada kondisi perempuan, baik dari segi kualitasnya maupun kuantitasnya. Perempuan dengan kualitas yang baik tentunya akan berpengaruh pada keluarganya, salah satunya dapat meningkatkan perkembangan dan pertumbuhan anak, sehingga akan menurunkan angka kematian bayi, kekurangan gizi, maupun putusnya pendidikan.

Pemberdayaan perempuan tidak hanya mencakup pada usaha memberdayakan saja, tetapi juga merupakan usaha untuk melindungi. Proses pemberdayaan sebagai usaha untuk 


\section{6-13 | HARKAT: Media Komunikasi Islam Tentang Gender dan Anak, 11 (1), 2015}

mencegah perempuan yang lemah bertambah lemah, karena ketidakmampuannya menghadapi yang kuat, sehingga adanya perlindungan dan pemihakan dalam memberdayakan perempuan sangat dibutuhkan. Melalui usaha perlindungan mencegah terjadinya persaingan yang tidak seimbang, serta menghindari the use of brute force yang dilakukan oleh yang kuat terhadap yang lemah, sehingga dengan ini posisi perempuan yang lemah tidak terpinggirkan. Namun, dalam proses pemberdayaan tidak menjadikan perempuan memiliki ketergantungan pada suatu program pemberdayaan, melainkan menjadikan perempuan mandiri, sehingga mampu mewujudkan kehidupan yang lebih baik.

Dalam pendidikan, menurut Ismah Salman (2005), semakin tinggi tingkat pendidikan perempuan, maka semakin sedikit jumlah perempuan yang lemah. Selain itu, tingkat pendidikan yang tinggi akan mempermudah akses perempuan dalam dunia perekonomian. Semakin tinggi tingkat pendidikan perempuan juga secara tidak langsung akan menjadikan perempuan mandiri dan mempunyai tekad dalam bertindak. Hal itu dikarenakan perempuan akan memiliki wawasan yang lebih luas dan cara pandang yang lebih kompleks. Dengan demikian, melalui pemberdayaan menjadikan posisi perempuan membaik, khususnya dalam kemandirian, serta mampu menguasai atas keputusan-keputusannya yang berkaitan dengan kehidupannya.

\section{Kredit Mikro sebagai Solusi Pemberdayaan Perempuan}

\section{UMKM (Usaha Mikro Kecil Menengah)}

Menurut Undang- Undang Nomor 20 Tahun 2008 tentang Usaha Mikro Kecil dan
Menengah (UMKM), usaha mikro adalah usaha produktif milik orang perorangan atau badan usaha perorangan yang memenuhi kriteria memiliki jumlah asset maksimal 30 juta dan jumlah omzet maksimal 50 juta. Usaha kecil adalah usaha ekonomi produktif yang berdiri sendiri, yang dilakukan oleh orang perorangan atau badan usaha yang bukan merupakan anak perusahaan atau bukan cabang perusahaan yang dimiliki, dikuasai, atau menjadi bagian baik langsung maupun tidak langsung dari usaha menengah atau usaha besar yang memenuhi kriteria dengan memiliki jumlah asset $>50$ juta500 juta dan jumlah omzet $>300$ juta-2,5 M. Usaha menengah adalah usaha ekonomi produktif yang berdiri sendiri, yang dilakukan oleh orang perseorangan atau badan usaha yang bukan merupakan anak perusahaan atau cabang perusahaan yang dimiliki, dikuasai, atau menjadi bagian baik langsung maupun tidak langsung dengan usaha kecil atau usaha besar dengan jumlah kekayaan bersih atau hasil penjualan tahunan dengan memiliki jumlah asset $>500$ juta-10 $\mathrm{M}$ dan jumlah omzet $>2,5 \mathrm{M}-50 \mathrm{M}$.

Badan Pusat Statisitik (BPS) telah mengelompokkan UMKM bedasarkan segi jumlah pekerjanya. Usaha yang memiliki 1-4 orang pekerja dikelompokkan sebagai usaha mikro, kemudian usaha yang memiliki 5-19 orang pekerja dikelompokkan sebagai usaha kecil, serta usaha yang memiliki 20-99 orang pekerja dikelompokkan sebagai usaha menengah. Namun, jika jumlah pekerja mencapai 100 orang atau lebih dikelompokkan sebagai usaha besar. Sebenarnya masih banyak pengertian ataupun definisi dari usaha kecil dan usaha menengah. Mengenai hal itu, dapat dilihat pada tabel berikut tentang usaha kecil dan usaha menengah yang dikutip dari berbagai sumber. 
Tabel : Definisi dan Kriteria Usaha Kecil dan Usaha Menengah

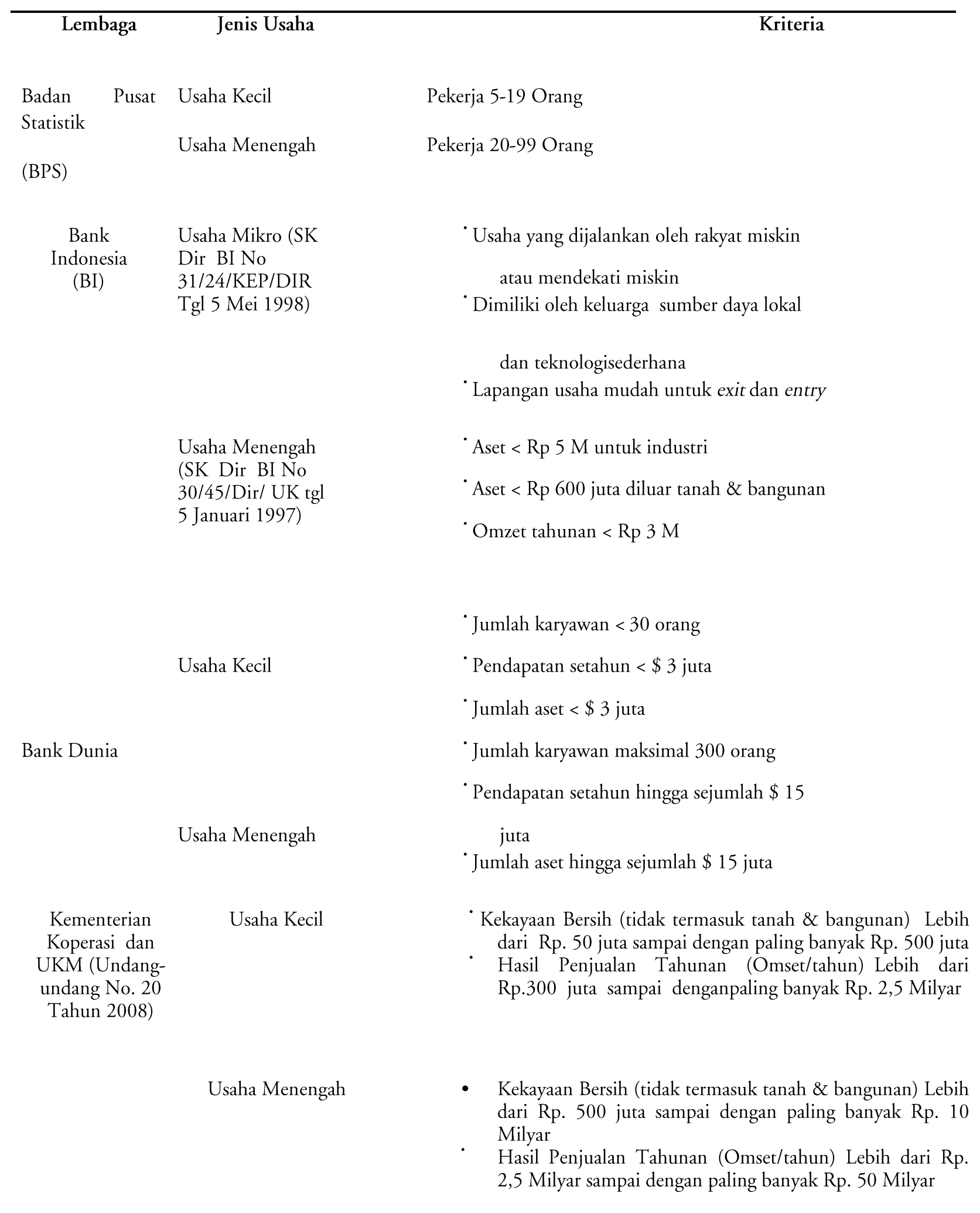

Sumber : (Sriyana, 2010) 


\section{8-13 | HARKAT: Media Komunikasi Islam Tentang Gender dan Anak, 11 (1), 2015}

Berdasarkan data dari BPS dalam Indikator Sosial Perempuan Indonesia tahun 1997, menunjukkan bahwa terdapat 63,54\% penduduk perempuan yang bekerja dalam pekerjaan utama di desa. Sementara untuk laki laki sebesar 61,43\%. Selain itu, data BPS tahun 2001 juga menunjukkan bahwa perempuan memegang 44,29\% kepemilikan usaha mikro di Indonesia (usaha kecil hanya 10,28\%). Walaupun jumlah tersebut lebih kecil dibanding kepemilikan laki-laki atas usaha mikro (yaitu $52,21 \%)$, tetapi diyakini secara nyata, persentase ini jauh lebih besar, karena data BPS tersebut didasarkan pada kepemilikan usaha secara formal dan bukan pelaku di lapangan.

\section{Gagasan Tentang Kredit Mikro}

Kredit mikro adalah program pemberian kredit berjumlah kecil kepada warga yang paling miskin untuk membiayai proyek yang dia kerjakan sendiri untuk menghasilkan pendapatan yang memungkinkan mereka peduli terhadap diri sendiri dan keluarganya (Woller, 2001). Menurut Naila Kabeer (2001), terdapat beberapa kecenderungan dalam program kredit mikro saat ini, yakni: 1) lebih banyak ditujukan untuk perempuan; 2) kredit disalurkan pada individu sebagai anggota suatu kelompok; 3) pembayaran kembali bergantung pada ketepatan dan kedisiplinan kelompok.

Menurut Suharto, sebagaimana dikutip oleh Khusnul Ashar (2011), program kredit mikro telah dilaksanakan di Indonesia sejak zaman penjajahan oleh Belanda, tetapi lambat laun semakin memiliki banyak ragam metode pelaksanaannya sejak kemerdekaan. Selain itu, terdapat beberapa hal yang melatar-belakangi munculnya gagasan kredit mikro, salah satunya akibat kegagalan lembaga kredit formal untuk mengatasi masalah kemiskinan. Pertimbangan adanya manfaat kredit mikro juga lebih diutamakan. Dalam hal ini, implementasi kredit mikro lebih efektif diterapkan, dibandingkan dengan program pengentasan kemiskinan yang lain, seperti program land-re-from (Ashar, 2011).

Diberbagai negara telah mencoba melaksanakan gagasan kredit mikro dalam pembangunannya. Bahkan, program kredit mikro tersebut juga berhasil dan memiliki keunggulan, sebagai contoh di Malaysia dan Korea Selatan yang memiliki keunggulan kredit mikro dalam sistem yang insentif, kontrol yang baik, dan sistem monitoringnya (Ashar, 2011). Kredit mikro di India didukung adanya lembaga Small Industry Development Bank of India (SIDBI) yang berperan mengkoordinasikan lembaga keuangan mikro, kecil dan menengah lembaga dengan kegiatan terkait yang dengan UMKM.

Program kredit mikro tidak hanya dijadikan instrumen agar kelompok miskin mempunyai akses pada lembaga keuangan formal, tetapi lebih lanjut telah menjadi suatu gerakan untuk memberdayakan masyarakat miskin, khususnya perempuan, yaitu dalam menanggulangi kemiskinan mereka, memperbaiki kualitashidup, dan

mengembangkan kemampuan dan pengetahuan kelompok sasaran untuk berpartisipasi aktif, baik dalam ekonomi maupun sosial (Rajivan, 2001).

\section{Relevansi Kredit Mikro terhadap Pemberdayaan Perempuan}

Melihat pada beberapa studi tentang kredit mikro, secara signifikan studi tersebut bertujuan untuk mengetahui bagaimana dampak kredit mikro terhadap perempuan sebagai penerimanya, khususnya apakah dampak tersebut mengarah pada pemberdayaan atau sebaliknya menjadikan pembebanan bagi para perempuan sebagai penerimanya, dimana hingga saat ini perempuan masih bertanggung jawab pada aktivitas-aktivitas domestik, sehingga semakin memperkuat tripple burden of women, yaitu dimana perempuan 
harus melakukan fungsi reproduksi, produksi, dan sekaligus fungsi sosial di masyarakat.

Terdapat beberapa pendapat penting, mengenai peminjaman kredit mikro pada perempuan lebih feasible atau efektif. Pertama, perempuan lebih mungkin untuk menggunakan pinjamannya bersama dengan suami atau anggota keluarga laki-laki mereka yang lain. Selanjutnya, disamping perempuan diuntungkan secara personal dan sosial, kredit mikro untuk perempuan juga diyakini memberikan manfaat yang lebih bagi keseluruhan keluarga dibanding kredit mikro untuk laki-laki. Selain itu, perempuan mempunyai kecenderungan untuk menggunakan hampir keseluruhan pendapatannya untuk keluarga, seberapa kecil pendapatan tersebut dan lebih memperhatikan masa depan anak-anak mereka dan siap untuk berkorban apa saja untuk mewujudkan masa depan tersebut (Kabeer, 2001). Perempuan juga dianggap lebih mampu bertahan dalam keadaan miskin dibandingkan laki-laki, sehingga jika kredit mikro diberikan kepada perempuan, maka secara tidak langsung perempuan akan berpikir lebih kreatif dalam memanfaatkannya.

Kedua, mengenai akses terhadap kredit mikro untuk perempuan mempunyai efek penting terhadap proses pemberdayaan perempuan. Pendapat ini mengimplikasikan kredit mikro pada tiga hal, yaitu: keberlanjutan keuangan yang mandiri, pengentasan kemiskinan, dan pemberdayaan para feminis. Pendapat ini menekankan juga bahwa program kredit mikro untuk perempuan mengarah pada pemberdayaan ekonomi para perempuan, secara lebih jauh akan mengarah pada pemberdayaan sosial, politik, dan hukum, yang pada akhirnya berkontribusi pada pembentukan social capital atau modal sosial yaitu dengan melalui berkembangnya jaringan antara mereka (Mahmud, 2003). Keterkaitan antara konsep pemberdayaan perempuan dengan kredit mikro adalah sebagai upaya untuk memberikan kesadaran mengenai situasi dan kondisi yang dihadapi, sehingga kemudian mengorganisasikan diri secara kolektif, dimana bertujuan untuk memperoleh akses secara lebih terhadap publik, serta untuk meningkatkan dan mengembangan tingkat perekonomian.

\section{Sistem Grameen Bank}

\section{Sekilas Tentang Grameen Bank}

Kata grameen berasal dari bahasa Bangali, "gram" yang berarti “desa", serta bentuk ajektifnya "grameen" berarti "pedesaan" atau "berasal dari desa" (Yunus, 2013). Grameen bank dipelopori oleh Prof. Muhammad Yunus, salah seorang dosen di Universitas Chittagong Bangladesh. Pendirian grameen bank diawali atas kegelisahannya terhadap kemiskinan yang tidak terselesaikan pada negaranya, sehingga beliau berinisiatif untuk membuat sebuah upaya dalam penyelesaian permasalahan kemiskinan di negaranya.

Dalam kurun waktu sekitar tahun 1975 hingga 1976 Prof. Muhammad Yunus melakukan pengamatan tentang permasalahan yang melanda negaranya, dimana terkait dengan tingkat kemiskinan. Dari hasil pengamatan Prof. Muhammad Yunus dapat menyimpulkan bahwa kemiskinan yang dihadapi masyarakat bukan dikarenakan adanya kemalasan maupun tidak adanya tingkat produktivitas, tetapi disebabkan adanya masalah yang mendasar dalam sistem sosialnya, yakni masalah kemiskinan struktural, sehingga masyarakat tidak memiliki kemampuan modal untuk meningkatkan usahanya, sedangkan mereka tidak memiliki jaminan untuk meminjam modal di bank. Namun, pada pengamatan selanjutnya Prof. Muhammad Yunus menganggap adanya jaminan yang lebih penting dari sekadar jaminan, yakni social capital.

Grameen bank adalah sebuah organisasi kredit mikro yang dimulai di Bangladesh dengan 


\section{0-13 | HARKAT: Media Komunikasi Islam Tentang Gender dan Anak, 11 (1), 2015}

memberikan pinjaman kecil kepada orang yang kurang mampu tanpa membutuhkan collateral. Sistem ini berdasarkan ide bahwa orang miskin memiliki kemampuan yang kurang digunakan, sehingga sistem grameen bank memfokuskan pada produktivitas. Yang berbeda dari kredit grameen bank adalah pinjaman diberikan kepada kelompok perempuan produktif yang masih berada dalam status sosial miskin. Pola grameen bank telah diadopsi oleh hampir 130 negara didunia (mayoritas dinegara Asia dan Afrika). Jika diterapkan dengan konsisten, pola grameen bank dapat mencapai tujuan untuk membantu perekonomian masyarakat miskin melalui perempuan.

\section{Konsep Grameen Bank}

Secara garis besar beberapa konsep dan prinsip operasional grameen bank dapat dilihat sebagai berikut:

Pertama, untuk lebih memudahkan masyarakat miskin dalam mengaksesnya, prosedur dan persyaratan pembiayaan dibuat secara sederhana. Tidak seperti perbankan pada umumnya yang mengharuskan nasabah untuk datang ke kantor bank, grameen bank menggunakan strategi jemput bola. Mulai dari proses pengajuan, pencairan serta pembayaran angsuran bisa dilakukan di tempat nasabah.

Kedua, skema dan plafond pembiayaan serta jadwal angsuran dibuat secara fleksibel, disesuaikan dengan kemampuan nasabah dalam membayar angsuran. Nasabah bisa melakukan angsuran pembiayaan secara harian, mingguan atau bulanan.

Ketiga, menerapkan konsep pembiayaan kelompok (group lending). Para calon nasabah yang mengajukan pembiayaan, akan digabungkan kedalam sebuah kelompok. Kelompok ini mempunyai beberapa fungsi, diantaranya sebagai sarana pembelajaran bersama para anggota, tempat untuk memperkuat rasa kekeluargaan dan kerjasama, serta memperkuat posisi tawar kelompok terhadap pihak lain. Sedangkan, bagi pihak grameen bank dengan terbentuknya kelompok, akan lebih memudahkan dalam melakukan pengawasan dan pembinaan.

Keempat, sebagai salah satu instrumen pengamanan dalam pembiayaan, maka pihak grameen bank menerapkan aturan tanggung jawab didalam kelompok. Misalnya, dalam satu kelompok yang mengajukan pembiayaan terdiri dari 5 (lima) orang anggota, maka dalam proses pencairannya tidak akan langsung dilakukan secara sekaligus, tetapi menggunakan mekanisme 2-2-1. Pada tahap pertama, dua orang anggota kelompok yang akan dicairkan, kemudian tahap berikutnya dua orang lagi, dan tahap terakhir satu orang. Biasanya penunjukan siapa yang akan mendapatkan pencairan tahap pertama dan tahap berikutnya merupakan hasil kesepakatan dari semua anggota kelompok. Ketua kelompok sebagai pemimpin akan mendapatkan jadwal terakhir pencairan pembiayaan. Jika terdapat kemacetan pembayaran angsuran, maka proses pencairan pada tahap berikutnya akan ditunda terlebih dahulu, sampai kemudian kelompok bisa menyelesaikan permasalahan kemacetan anggotanya.

Kelima, pihak grameen bank akan memberikan pendampingan secara terstruktur kepada kelompok nasabah. Secara periodik akan diberikan materi-materi yang akan memperkuat karakter dan rasa kepercayaan diri, pemberian bimbingan teknis dan keterampilan usaha, pembukuan, pemasaran dan materi-materi lain yang dapat mendukung perkembangan usahanya.

Keenam, untuk membantu masyarakat miskin dalam upaya mempunyai asset sendiri, maka pihak grameen bank akan mewajibkan kepada nasabahnya untuk menyisihkan sebagian keuntungan yang diperoleh dari hasil usaha, untuk dijadikan sebagai tabungan. Bahkan, bagi para nasabah yang telah meminjam dan usahanya terus berkembang, maka akan diberikan 
kesempatan untuk membeli sebagian saham grameen bank, sehingga kepemilikan grameen bank diharapkan sebagai kepemilikan nasabah (kepemilikan bersama).

\section{Peran Grameen Bank terhadap Pemberdayaan Perempuan}

Grameen bank di Bangladesh telah memiliki 1.181 cabang, yang tersebar di 42.127 desa, serta didukung 11.777 staf. Namun, sampai dengan akhir tahun 2005, grameen bank telah memiliki cabang sebanyak 2.226 di 71.371 center (desa). Selain itu, telah menyalurkan kredit sebanyak US\$ 3,9 milyar kepada 2,6 juta debitur yang mayoritas $95 \%$ perempuan. Model grameen bank juga telah diikuti oleh lebih dari 250 lembaga keuangan mikro dihampir 100 negara.

Terdapat beberapa dampak positif adanya grameen bank dengan sistem dan konsep yang tidak memberatkan bagi nasabahnya. Menurut Prof. Muhammad Yunus dampak positif tersebut berupa kemandirian, sikap saling membantu dan gotong royong, meningkatkan potensi ekonomi, adanya perwakilan dan pertanggung jawaban para pemimpin kelompok, keterbukaan dalam prosedur pengambilan keputusan dan manajemen, menumbuhkan budaya menabung, kedisiplinan, dan bisa dipercaya, serta mengembangkan diri melalui pertukaran ide dan gagasan.

Peran grameen bank dalam pemberdayaan perempuan miskin cukup berhasil. Hal ini bisa dilihat pada beberapa desa di Bangladesh, bahwa kondisi perempuannya telah mulai bangkit dan membaik, khususnya dalam meningkatkan produktivitas. Dalam hal ini, grameen bank juga telah berhasil menciptakan lapangan pekerjaan bagi perempuan, khususnya bagi perempuan yang memiliki ekonomi miskin, sehingga ekonomi perempuan miskin secara perlahan akan menjadi lebih baik. Disamping itu, kondisi tersebut juga berpengaruh terhadap keluarga, yang dapat dilihat pada jumlah anak putus pendidikan yang berkurang, serta gizi pada anak juga tercukupi. Oleh sebab itu, peran grameen bank tidak hanya pada pemberdayaan perempuan, tetapi juga dalam upaya meningkatkan kualitas keluarga, khususnya anak sebagai generasi penerus bangsa.

\section{PENUTUP}

\section{Simpulan}

Berdasarkan pembahasan di atas, maka penulis dapat memberikan beberapa kesimpulan, antara lain:

1. Pemberdayaan perempuan bertujuan untuk meningkatkan kualitas perempuan dalam berbagai aspek kehidupan, seperti: ekonomi, sosial, dan politik. Dengan pemberdayaan perempuan diharapkan memberikan dampak yang baik terhadap keluarga, khususnya dalam meningkatkan kualitas anak.

2. Kredit mikro merupakan salah satu solusi dalam pemberdayaan perempuan. Dalam hal ini, pemberian kredit mikro terhadap perempuan memberikan peluang dan kesempatan dalam pemanfaatannya secara maksimal.

3. Penerapan sistem grameen bank di Bangladesh membuktikan manfaat secara global terhadap pemberdayaan perempuan, sehingga banyak diaplikasikan oleh banyak negara. Konsep dan sistem grameen bank juga dapat diterapkan dalam masyarakat Indonesia. Dengan melihat kondisi ekonomi masyarakat pedesaan dan sosio-kulturnya menjadikan grameen bank dapat diterapkan dengan baik di Indonesia.

4. Keberhasilan grameen bank salah satunya menciptakan lapangan pekerjaan bagi perempuan yang memiliki ekonomi miskin. Selain itu, lapangan pekerjaan tersebut juga termasuk dalam lapangan pekerjaan yang 


\section{2-13 | HARKAT: Media Komunikasi Islam Tentang Gender dan Anak, 11 (1), 2015}

ramah bagi perempuan, serta menimbulkan dampak yang baik bagi anak.

\section{Saran}

Berdasarkan pembahasan di atas, maka penulis dapat memberikan beberapa saran, antara lain:

1. Dalam melancarkan dan mensukseskan pemberdayaan perempuan membutuhkan konsep dan rumusan strategi yang baik sebelum diaplikasikan.

2. Pemberian kredit mikro terhadap perempuan perlu diaplikasikan secara meluas dan tersistem dengan baik, sehingga akan menghasilkan efektivitas.

3. Penerapan grameen bank di Indonesia dapat dijadikan solusi dalam memberdayakan perempuan desa yang memiliki ekonomi miskin. Selain itu, dibutuhkan upaya dalam menyadarkan masyarakat tentang pemberdayaan perempuan.

4. Untuk mewujudkan upaya pemberdayaan perempuan dibutuhkan peran dari semua pihak, khususnya pemerintah sebagai pemegang kekuasaan dalam menetapkan kebijakan.

\section{DAFTAR PUSTAKA}

Arikunto, Suharsimi. Prosedur Penelitian Suatu Pendekatan Praktik. Jakarta : P.T. Rineka Cipta. 2009

Ashar, Khusnul. Analisis terhadap Kesinambungan Lembaga Pembiayaan Pedesaan dalam Mendukung Usaha Mikro, Kecil, dan Menengah. Journal of Indonesian Applied Economics, V, 1. Mei 2011
Departemen Pengembengen Akses Keuangan dan UMKM Bank Indonesia. Booklet Keuangan Inklusif. 2014

Kabeer, Naila . Conflicts Over Credit : Re Evaluating the Empowerment Potential of Loans to Women in Rural Bangladesh. World Development. 29(1). 2001

Mahmud, Simeen. Actually How Empowering in Micro Credit. Development and Change. 34 (4). 2003

Nur, Tri Hastuti. Partisipasi Politik Perempuan Dalam Kebijakan Publik. Jurnal Demokrasi. Vol. 1 No. 1. November 2003

Oxford English Dictionary. 2008

Panjaitan, Rosintan D. M., Drioadisuryo, dan Kathleen Cloud. Gender, Self Employment and a Micro Credit Program: An Indonesian Case Study. The Quarterly Review of Economics and Finance. 39 (5). 1999

Projono, O.S dan Pranarka, A.M.W. Pemberdayan: Konsep, Kebijakan dan Implementasi. Jakarta : CSIS. 1996

Pusat Bahasa Departemen Pendidikan Nasional. Kamus Besar Bahasa Indonesia. Jakarta : Balai Pustaka. 2002

Rajivan, Anuradha. Credit and Women's Empowerm ent : A Case Study Of SML (SHARE Microfinance Ltd.,). United Nations Development Program (UNDP) DRAF. (http://www.undp.org. in/report/wkspsclmblizn/casestudy ofsml.htm). Diakses 12 September 2015

Salman, Ismah. Keluarga Sakinah dalam Aisyiyah. Jakarta : PSAP Muhammadiyah. 2005 
Sofyan, Ismail. Wanita Utama Nusantara: dalam Lintasan Sejarah. Jakarta: Jayakarta Agung. 1994

Sriyana, Jaka. Strategi Pengembangan Usaha Kecil dan Menengah (UKM): Studi Kasus di Kabupaten Bantul. Makalah Simposium Nasional 2010: Menuju Purworejo Dinamis dan Kreatif

Sutoro, Eko. Pemberdayaan Masyarakat Desa. Samarinda: Badan Diklat Provinsi Kaltim. 2002

Suwondo, Kutut. Civil Society di Aras Lokal: Perkembangan Hubungan Antara Rakyat dan Negara di Pedesaan Jawa. Yogyakarta: Pustaka Pelajar dan Percik. 2005

Usman, Sunyoto. Pembangunan dan Pemberdayaan Masyarakat. Yogyakarta: Pustaka Pelajar. 2004
Woller, Garry M. dan Warner Woodworth. Micro Credit and Third World Development Policy. Policy Studies Journal. 29 (2). 2001

Yunus, Muhammad. Bank Kaum Miskin. Terj. Tangerang Timur: Marjin Kiri. 2013

Zakiyah. Pemberdayaan Perempuan. Jurnal Pengkajian Masalah Sosial Keagamaan, XVII, 01. Januari-Juni 2010

http://gampito.blogspot.co.id/2009/02/gramee n-bank-dikembangkan-pertama-kali.html diakses pada 15 September 2015 